\title{
ACCOMMODATION INFRASTRUCTURE IN THE MOUNTAINOUS AREA OF SUCEAVA COUNTY. ANALYSIS FROM THE TRIPLE PERSPECTIVE
}

DOI: https://doi.org/10.18509/GBP210297d

UDC: 338.488.2(498:23.0)

\author{
Liliana Daniela Diacon \\ Luminița Mirela Lăzărescu \\ Vasile Efros \\ Cristian Ciubotaru \\ Ștefan cel Mare University of Suceava, Faculty of History and Geography, \\ Departament of Geography, Romania
}

\begin{abstract}
The mountainous area of Suceava County presents real opportunities for tourist development, having numerous unique and well-preserved tourist resources, highlighted by their antiquity, originality and accessibility, a large number of traditional rural households and a generous number of accommodation spaces.

Starting from the hypothesis that the tourist offer of the mountain area is attractive, this research aims to analyze the size of accommodation infrastructure in the mountainous area of Suceava County based on data provided by national authorities National Institute of Statistics and National Authority for Tourism and site specialized for the promotion of accommodation structures. The research methodology was performed by processing the data using Excel and the elaboration of thematic maps based on the results obtained. The data and information were obtained by studying specialized articles, on similar studies from other.

In conclusion, based on the data provided by official sources and specialized sites, a discrepancy can be found in terms of the total number of reception structures operating at this time in the Suceava mountain area and implicitly leads to different data regarding the indicator of overnight stays in tourist accommodation structures.
\end{abstract}

Keywords: rural tourism, mountain area, accommodation structures

\section{INTRODUCTION}

Rural tourism is always practiced, but spontaneously, sporadically, casually and especially unorganized. Rural tourism, in an organized way, in the mountainous area of Suceava county is of recent date, having the same trajectory with the rural tourism at the level of the entire country. The beginnings of the organization of rural tourism in Romania is placed in the period 1973-1974, when the political regime of the time, launches the action of "tourist villages", identified in the ethnographic areas of the country [9]. In many EU Member States, rural tourism is seen as a strategy for the future, which can contribute to the economic and social development of local communities, to create jobs and reduce migration [12], [17]. At the same time, rural tourism is considered among the most dynamic forms of travel, having multiple advantages for both the tourist and the host [11]. Referring to the area of Romania, $87.1 \%$ correspond to the rural environment, and $43.59 \%$ of the country's population lives in the village, thus, rural tourism involves the following aspects: the existence of rural spaces, the preservation of rural functionality, the preservation of a rural infrastructure, the preservation of the traditional way of life, the 
preservation of the specific cultural identity [5], [10]. The village, much approached, carries with it a special human significance, identified with the traditions of the place and the religious holidays kept with sanctity [1], or it offers a mythological tourist potential, especially the mountain pastoral form [17], or it represents the return to nature and to the rural communities [8]. In other words, the village becomes the host of complex activities that promote tradition, a return to its origins, the discovery of nature and beauty.

The Romanian village has successfully gone through less favorable periods of history, preserving to a large extent unaltered the purity of its culture. The development of rural tourism means increasing living standards, stabilizing the population, maintaining cultural identity [7], increasing economic power at local and national level [13], [14], while maintaining ecological balance and protecting the natural environment [17].

The road to success is paved by an overall development of the rural environment, based on a moderate increase over time and to the benefit of the rural area because a rapid or disorderly development of rural tourism can damage the environment, and can affect the local population [6], [13].

\section{STUDY AREA}

The study area overlaps with the mountain area of Suceava County which occupies 53\% of the entire county and is integrated into the chain of the Eastern Carpathians [4] being composed of 36 communes, comprising massive and complex peaks separated from each other by deep valleys [2], [3]. The distinguishing mountain units are: Suhard and Călimani Massifs, Giumalău - Rarău Massifs, Bistriţa, Stânişoara Mountains, Obcinii Feredeului and Mestecăniș.

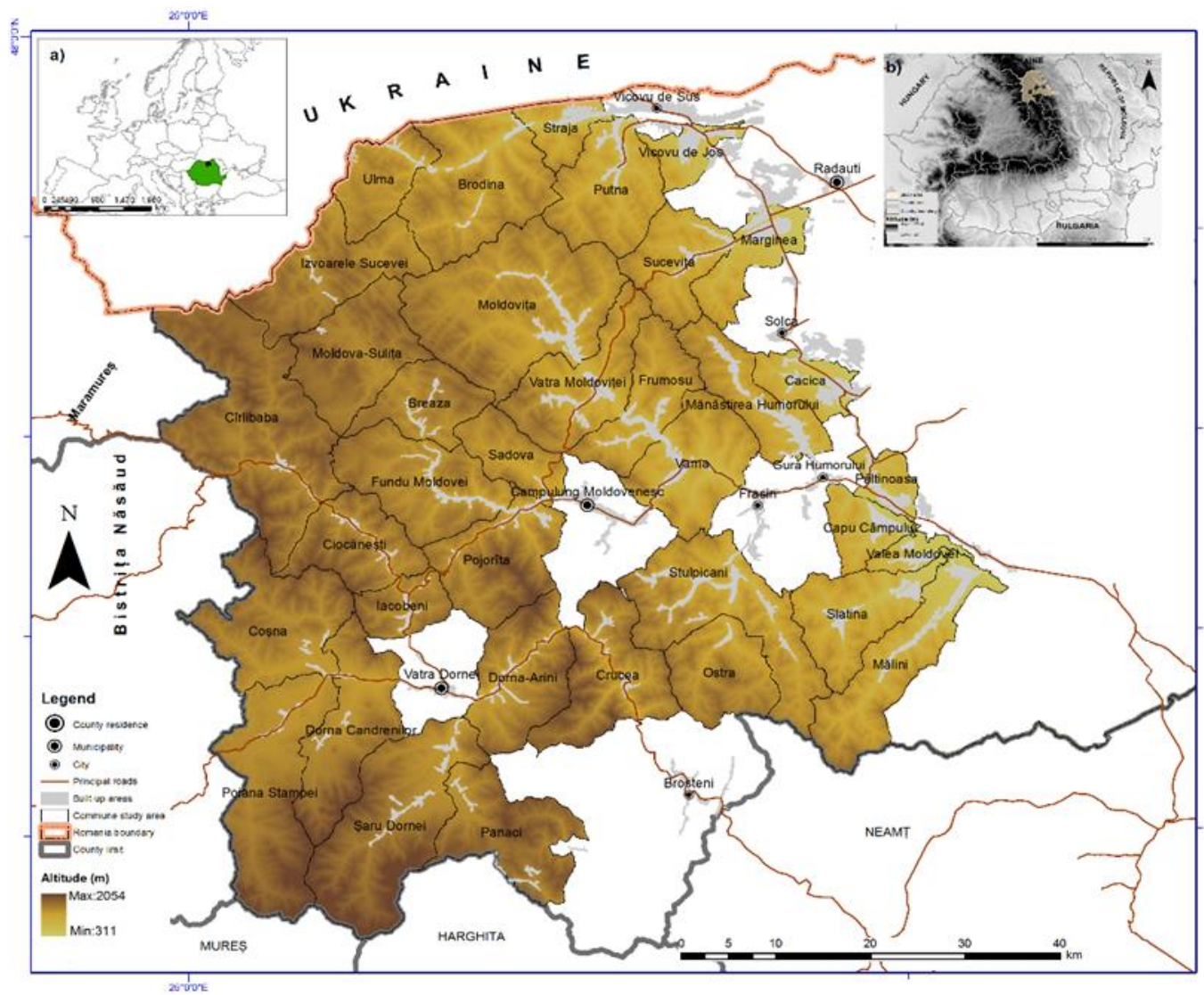

Figure 1. Geographical location of the studied area 


\section{RESEARCH METHODS}

The research focused on the comparative analysis of the number of tourist reception structures with accommodation functions that can carry out the activity in the mountainous area of Suceava County, based on data collected from official sources of information, such as the National Tourism Authority (ANT), the National Institute of Statistics (INS) and websites specializing in tourism promotion. The objectives of the study were to capture in figures the impact of the pandemic on the number of reception structures in the mountainous rural area, transparency and good cooperation between state institutions and sites specialized in tourism promotion.

The study is structured in two parts: the first part analyzes the evolution of reception structures in 2020, a year strongly influenced by the global pandemic of the Sars Cov 2 virus, compared to 2019, based on data provided by the National Institute of Statistics. In the second stage of the research is presented a comparative analysis of the total number of reception structures in the 36 communes for 2020 from three perspectives (National Authority for Tourism, National Institute of Statistics and websites specialized in tourism promotion).

The comparative analysis was also used for similar studies from other regions of Romania, (Răcăşan, 2017) [14], but we adapted it to the mountain area by introducing the infoturist.ro website. being the most used online booking site in Romania according to the study conducted by trafic.ro.In order to highlight the differences between the three sources of information, the data were recorded and processed using Microsoft Excel, maps materialized through spatial representations in the GIS program were used, methods that were the basis of the interpretive approach, as well as the formulation of the conclusions of the present study. The cartographic method is validated by the map of the study area as well as the thematic map showing with the help of conventional signs, the number of reception structures with accommodation function in the chosen area. The comparative method is highlighted by the inserted graphs and maps with a high degree of expressiveness by choosing simple exposure methods in order to capture the essence of the researched phenomenon.

\section{RESULTS AND DISSCUSIONS}

From the analysis of the data provided by INS [18], it is found that in Romania, in 2020, compared to the same period of 2019, the tourist accommodation capacity increased by $0.4 \%$ in the number of available places, and the number of accommodation structures with accommodation function increased by $2.5 \%$.

Analyzing the number of reception structures in the mountain area of Suceava County, we find that both the total number of places made available to tourists and the number of reception structures in this area, they experienced a significant increase in 2020, despite the fact that during this period there were also reception structures that stopped working or underwent major repairs. Therefore, according to the data provided by INS, in 2019 at the level of the Suceava mountain area, there was an accommodation capacity of 3313 places, and in 2020 there was a capacity of 3646 places, it results that the year 2020 brought an additional 333 places accommodation compared to 2019.

Regarding the number of tourist reception structures, in 2019 there were a number of 230 structures, and in 2020 a number of 246 structures, despite the fact that in some communes, the number of accommodation structures decreased. (Figure 2) 


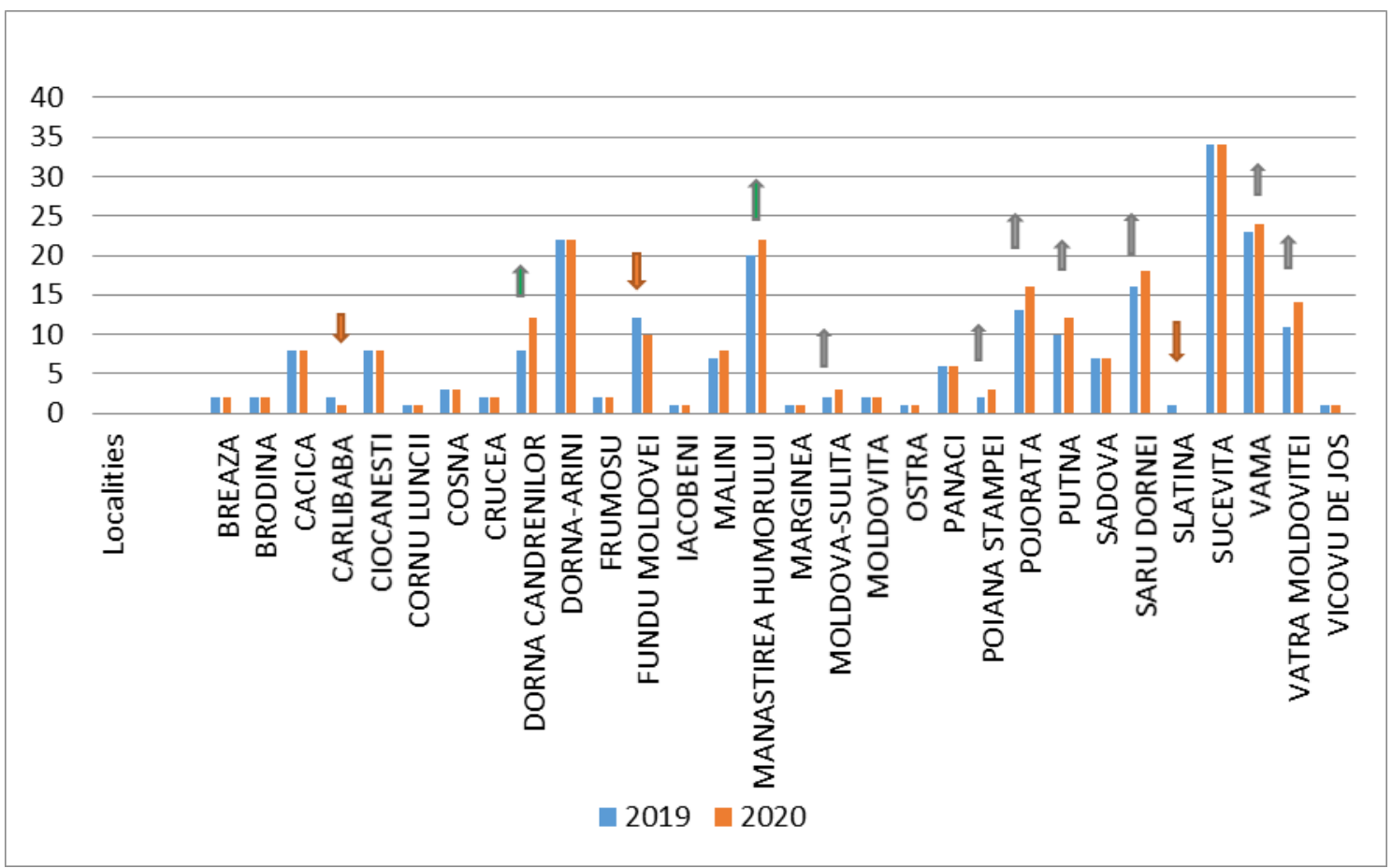

Figure.2 Tourist reception structures (sourse http://statistici.insse.ro:8077/tempoonline/\#/pages/tables/insse-table)

Given the increase in 2020 in the number of accommodation facilities and the number of places they offer, it is necessary to analyze the total number of tourists arriving in this area in the last two years. The statistics show a change in the behavior of tourists in 2020, compared to the same period of 2019 , motivated by restrictions imposed on the population to combat and prevent infection with the Sars Cov virus 2. In 2020, a smaller number of tourists was registered in the first months, registering in many localities zero tourists in April and May, motivated by the restrictions imposed by the authorities of Suceava county, period in which the quarantine was installed at the level of Suceava municipality and the metropolitan area, followed by an increase in the number of arrivals (June, July, August when the legislative relaxations appeared).

However, comparing the data with the same period of 2019, there is a decrease in the number of tourists arriving by $35 \%$. From the first part of the study, we conclude that the year 2020 brought more reception structures and implicitly accommodation in this area, but the number of arriving tourists decreased. A possible cause of the increase in the number of reception structures in the mountainous rural area is the attraction of European structural and investment funds from 2014-2020, which led to the construction of tourist pensions and agritourism pensions. The second part of the study aimed to compare the number of reception structures existing at the end of 2020, in terms of data provided by INS [17], ANT [22] and specialized sites, thus resulting in a triple perspective.

From Figure 3. it can be observed that the data provided by INS and ANT regarding the number of existing accommodation structures in the rural area of Suceava, do not correspond to the number of reception structures promoted online. Due to its current trend of booking tourist spaces with the help of competent sites, we analyzed the number of accommodation structures with accommodation function that appear on various profile sites. In the virtual world, there are sites that serve as tourist guides, and in their top, there is www.turistinfo.ro, [19] according to the trafic.ro site [20]. 


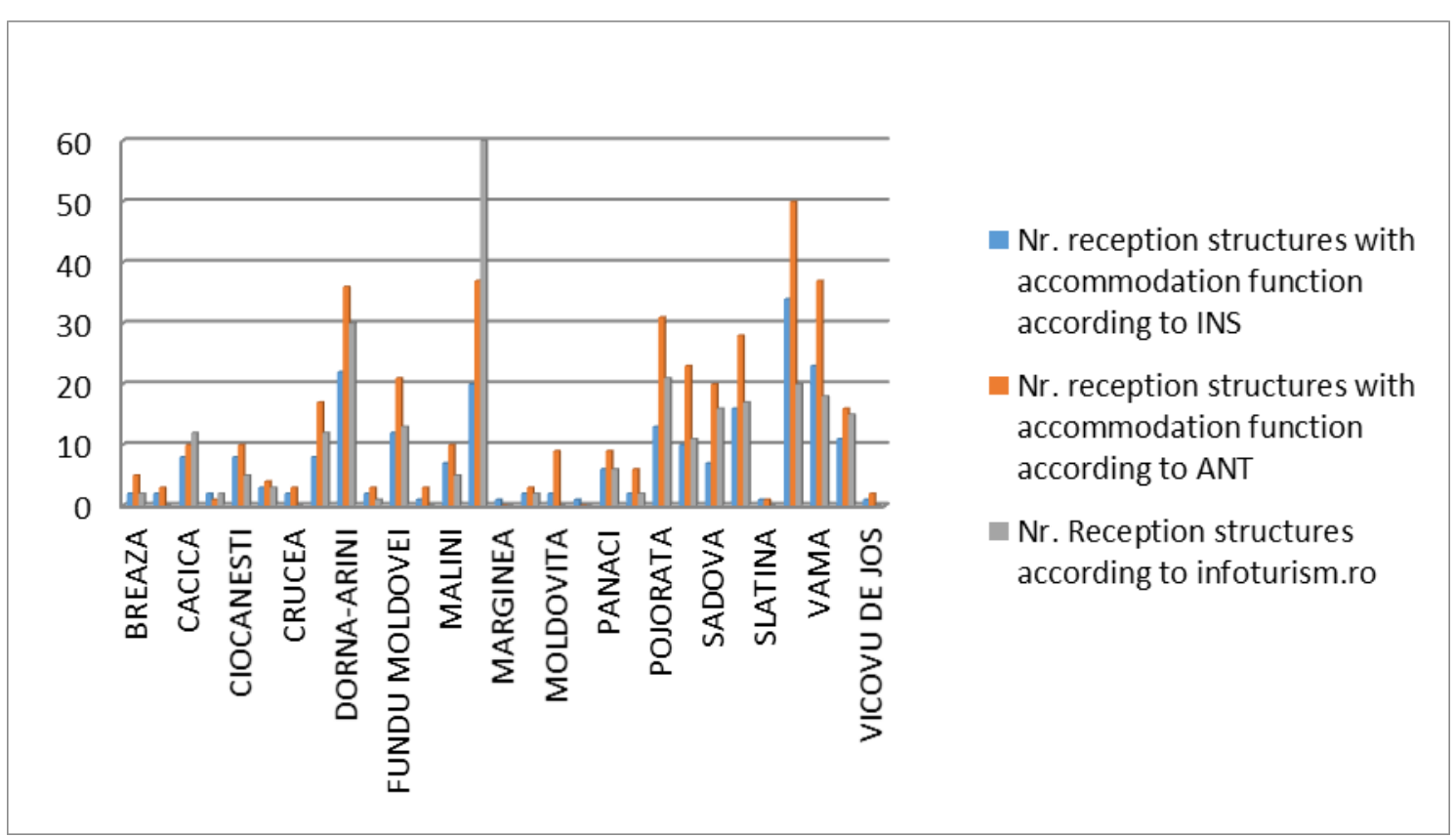

Figure 3. Number of reception structures in the Suceava rural area (Source: INS, ANT and infoturist.ro)

The site was created in a transparent and relevant manner (real pictures of the accommodation units and their addresses, room price, facilities, etc.). Turistinfo.ro makes available to each accommodation unit, based on a service contract, a space managed by the unit itself, for the publication of the tourist offer. It can be seen in the table with number 3, the discrepancy between the official data and the tourist promotion sites, from which it results that the official data are partial and incomplete. Moreover, in some communes in the Suceava mountain area, zero reception structures are declared on the I.N.S website, but on the A.N.T and the website www.infoturist.ro, there are promoted tourist reception structures with accommodation function. For example in Izvoarele Sucevei Commune according to the data provided by INS, there are no tourist accommodation places available, according to ANT there are 2 tourist reception structures totaling 18 places, and on the website www.infoturist.ro, there are 2 reception structures, classified with three stars each, having a total of 13 accommodation spaces with 26 places available. Which means that the reception structures on infoturist.ro are different from those mentioned by ANT, and their number is actually higher. The legislation in force in Romania stipulates that the reception structures under 5 accommodation places are not included in the statistics, or, on www.infoturist.ro, we find promoted and made available houses with 2 rooms (4 places), which results in a first difference in the number of tourist reception structures. We also found that in some localities, reception structures with accommodation function known locally and nationally, is not listed on the site www.infoturist.ro but the tourist offer can be seen on its own website or on booking.ro. [21] (ex: Tourist stop at La Filuță). The discrepancy between the figures provided by the official sources of information, respectively INS and ANT, can be explained by the lack of a common procedure in order to obtain the operation authorization and the classification certificate. These mandatory documents for the proper functioning of the reception structures are obtained from different institutions, hence the lack of transparency and poor collaboration between the two institutions. In the legislation in force, according to the Methodological Norms regarding the issuance of classification certificates, in article 2, point b) within the structures of tourist reception we find 
apartments and rooms for rent in family dwellings, which can be classified, but the INS does not include this form of accommodation among the accommodation structures, or these structures appear reported by the ANT, or are promoted on specialty sites where the differences in the three data collection sources result. The non-declaration of the tourism activity of some tourist reception structures also leads to discrepancy between the three sources of information. The underlined elements of discrepancy implicitly lead to different data regarding the total indicator of overnight stays in the tourist accommodation structures.

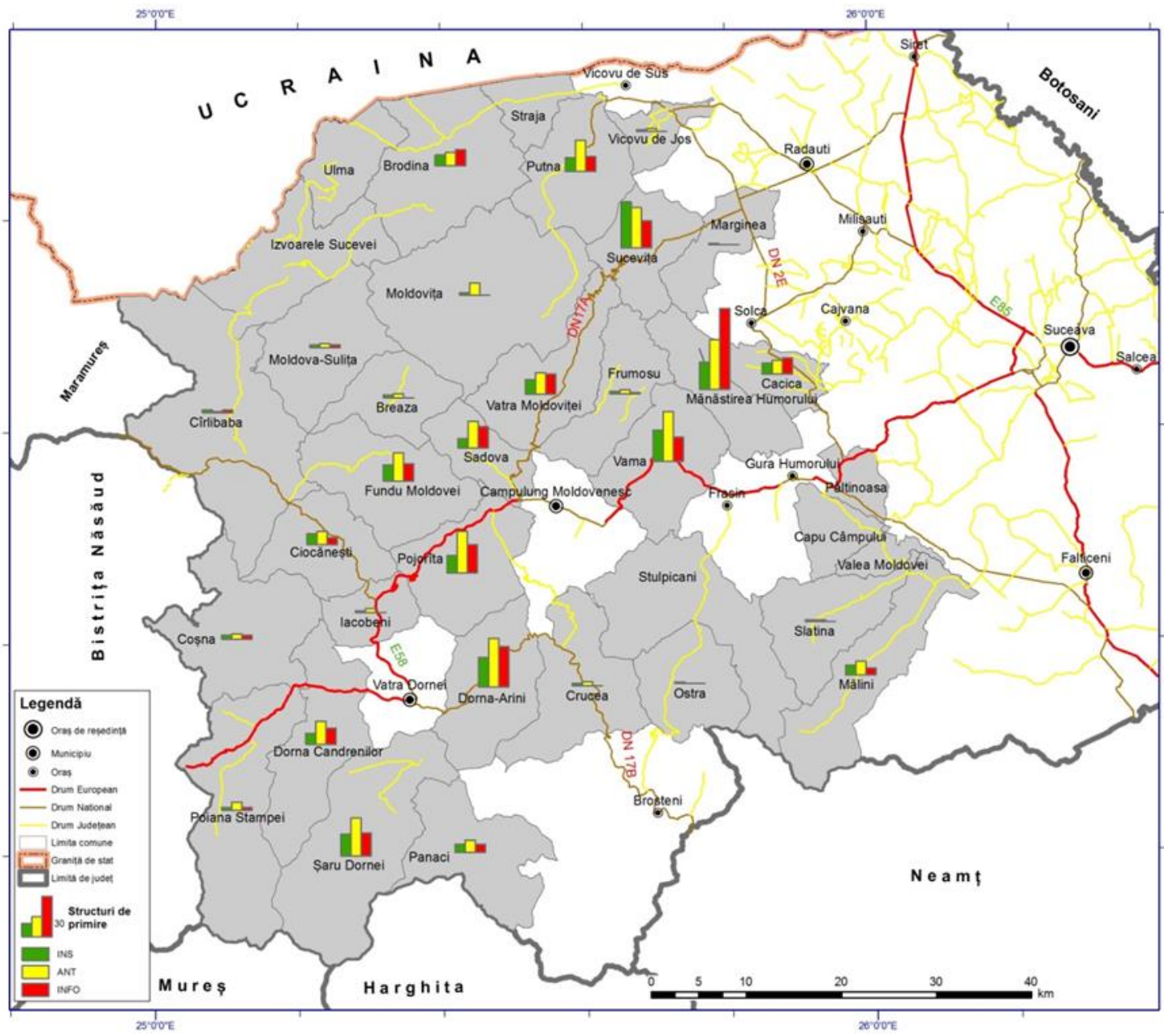

Figure 4. Reception structures in the mountain area (triple perspective)

\section{CONCLUSIONS}

The present study reveals that the year 2020 brought on the tourist market new reception structures and implicitly accommodation places in the Suceava mountain area, but the number of arriving tourists decreased. Based on data provided by official sources and specialized sites, can be observed in the mountainous area of Suceava, a discrepancy in the total number of accommodation structures at the end of 2020. The discrepancy between the official data and the tourist promotion sites, regarding the number of tourist reception structures denotes that the official data are partial and incomplete.

The legislation in force in Romania stipulates that the reception structures under 5 accommodation places are not included in the statistics, however, ANT and the 
specialized sites promote tourist reception structures with 2 rooms (4 places), which results in a first difference in the total number of tourist reception structures.

Mandatory documents for the proper functioning of the reception structures are obtained from different institutions, unconditionally to each other, resulting in a lack of transparency. Within the tourist reception structures we find apartments and rooms for rent in family homes, which can be classified, however, the INS does not include this form of accommodation among the accommodation structures, but these structures are reported by the ANT or are promoted on specialized sites, which leads to differences between the three sources of data collection. The non-declaration of the tourist activity of some tourist reception structures also leads to the discrepancy between the three sources of information. In order to eliminate the discrepancies highlighted, the competent authorities must follow the same indicators, to have a reciprocal conditioning in the elaboration of the classification certificates and the operation authorization in order to lead to the same figures of the tourist reception structures.

\section{Acknowledgement}

This work is supported by project POCU 125040, entitled "Development of the tertiary university education to support the economic growth - PROGRESSIO", co-financed by the European Social Fund under the Human Capital Operational Program 2014-2020

\section{REFERENCES}

[1] Antonescu, D., Antonescu R. M. Sustainable development of agro-tourism in European Union and Romania, in MPRA Paper, no.56653, https://mpra.ub.uni-muenchen.de/56653/ pp 119-128, 2015.

[2] Barbu, N. Obcinele Bucovinei, Editura științifică și enciclopedică, București, 1976, pp

[3] Bojoi, I. et al. Suceava - Ghid turistic al județului, Editura Sport -Turism, București, 1979, pp 7-25.

[4] Brândus, C., Cristea, Al. I., -Județul Suceava- Seria Judetele României, Editura Academiei Române, București 2013, pp 86- 88

[5] Cândea, M. Potențialul turistic al României, Editura Universitară, București, pp 15, 2006

[6] Gogonea M., R. Posibilități de integrare a produsului turistic rural pe piața turistică europeană, in Journal of Tourism, No. 3, 2007, pp. 29-35.

[7] Grigorcea, N. Turismul rural românesc și creșterea economică, in Turismul rural românesc în contextul dezvoltarii durabile. Actualitate și perspective, Editura Tehnopress, Volumul XX , Iași , 2010, , pp 42-45.

[8] Nistoreanu, P., The trilateral relationship ecotourism- sustainable tourism- slow travel among nature in the line with authentic tourism lovers, in Journal of tourism, No.11, 2011, pp. 34-37

[9] Nistoreanu, P.,Turismul rural o afacere mică cu perspective mari, Editura Didactică şi Pedagogică, București, 1999

[10] Nistoreanu, P. Aprecieri asupra fenomenului turistic rural, in Revista de turism, No. 3, pp 16-23, 2007.

[11]Nistoreanu Puiu, Ghereș, M., ”Turismul rural”, Editura C. H. Beck, București, 2010.

[12] Nițescu, A. Development of rural tourism in the European context, in Annals of the Constantin Brâncuși University of Târgu Jiu, Economy Serieis, Volume II, Issue 1, pp.199-202, 2015.

[13] Rey, R. Munții și secolul XXI, Editura Terra Nostra, Iași. 2013 
[14] Răcățan B. S., (2017), ”Turismul în spațiul rural montan și de contact marginal din județul Cluj”, rezumatul tezei de doctorat, coordonator științific, Ciangă N., Universitatea Babeș-Bolyai, Cluj-Napoca.

[15] Săvoiu G., et al. Mitologie românească și turism rural, in Turismul rural românesc în contextul dezvoltării durabile. Actualitate și perspective, Volumul XX, Editura Tehnopress, Iași, 2010 pp. 202-212.

[16] Slusariuc, G. C., Simina A. E. Evolutions of Rural Tourism in Romania and Europe, in Economic Sciences Series, Volume XVIII, pp. 182-185, 2018.

[17] Legea muntelui no 197/2018

[18] National Institute of Statistic. Numărul pensiunilor și pensiunilor agro-turistice din județul Suceava tempo-online/\#/pages/tables/insse-table.

[19] www.infoturist.ro

[20] www. trafic.ro

[21] www.booking.ro

[22 http://turism.gov.ro/web/ 